\title{
Implementasi Pendidikan Ketrampilan dalam Membentuk Imajinasi Anak Didik di TK Plus "Darul Athfal” Kediri Indonesia
}

\author{
Fadhil Akbar \\ Sekolah Tinggi Ilmu Syari’ah Faqih Asy'ari Kediri, Indonesia \\ e-mail: fadhilstillah@gmail.com
}

\begin{abstract}
Pendidikan ketrampilan merupakan tuntutan kehidupan yang sangat penting. Ketrampilan akan menghasilkan berbagai inovasi dan perkembangan baru dalam suatu kehidupan. Suatu individu dan organisasi yang kreatif akan selalu dibutuhkan oleh lingkungannya, karena mereka dapat mampu memenuhi kebutuhan lingkungan yang terus berubah dan mampu untuk bertahan dalam kompetisi global yang dinamis dan ketat. Potensi kreatif yang sangat penting tersebut pada dasarnya dimiliki oleh setiap anak. Anak memiliki ciri individu yang kreatif, misalnya: rasa ingin tahu yang besar, senang bertanya, imajinasi yang tinggi, berani menghadapi risiko, senang akan hal-hal yang baru, dan lain sebagainya.

Dari uraian di atas, maka dapat dirumuskan masalah penelitian sebagai berikut (1) Bagaimana implementasi pendidikan ketrampilan yang ada di TK Plus Darul Athfal Sumbersari Kencong Kepung Kediri (2) Apa saja faktor pendukung dan penghambat pendidikan ketrampilan dalam membentuk imajinasi anak didik di TK Plus Darul Athfal Sumbersari Kencong Kepung Kediri?

Penelitian ini merupakan penelitian kualitatif dengan menggunakan pendekatan berparadigma deskriptif-kualitatif yang bersifat fenomenologi. Pelaksanaan penelitian ini di TK Plus Darul Athfl Sumbersari Kencong Kepung Kediri, Pengumpulan data menggunakan observasi, wawancara, dan dokumentasi.

Kata kunci: ketrampilan, pembentukan imajinasi
\end{abstract}

\section{Pendahuluan}

Taman kanak-kanak merupakan salah satu bentuk pendidikan pra-sekolah yang ada di jalur pendidikan sekolah. Pendidikan pra-sekolah adalah pendidikan untuk membantu pertumbuhan dan perkembangan jasmani dan rohani anak di luar lingkungan keluarga sebelum memasuki pendidikan dasar. Usaha ini dilakukan supaya anak usia 4-6 tahun lebih siap mengikuti kehidupan selanjutnya.

Sebagaimana terdapat dalam garis-garis besar program kegiatan belajar taman kanak-kanak, bahwa taman kanak-kanak didirikan sebagai usaha mengembangkan seluruh segi kepribadian anak didik dalam rangka menjembatani pendidikan dalam keluarga dan pendidikan sekolah. Adapun yang menjadi tujuan program kegiatan belajar anak taman kanak-kanak adalah untuk membantu meletakkan dasar ke arah perkembangan sikap, pengetahuan, ketrampilan, dan daya cipta yang diperlukan oleh anak didik dalam menyesuaikan diri dengan lingkungannya dan untuk pertumbuhan dan perkembangan selanjutnya. ${ }^{1}$

Masa kanak-kanak adalah masa yang peka untuk menerima berbagai macam rangsangan dari lingkungan guna menunjang perkembangan jasmani dan rohani yang ikut menentukan keberhasilan anak didik. Masa anak-anak juga masa bermain, oleh sebab itu kegiatan belajar mengajar di taman kanakkanak diberikan melalui bermain sambil belajar dan belajar sambil bermain.

Tujuan program kegiatan belajar taman kanakkanak adalah daya cipta atau dengan istilah lain kreativitas. Kreativitas merupakan wujud dari ketrampilan yang keluar dari imajinasi anak didik. Tetapi ternyata dalam pelaksanaannya masih banyak ditemukan kesulitan yang berkenaan dengan bagaimana mengembangkan kreativitas pada anak taman kanak-kanak. Kesulitan atau hambatan tersebut mungkin berasal dari program apa yang seharusnya dikembangkan oleh guru, karakteristik guru seperti apa yang dapat mengembangkan

\footnotetext{
1 Yeni Rahmawati, Euis Kurniati, Strategi Perkembangan Kreativitas Pada Anak Usia Taman Kanak-Kanak, (Jakarta: Kencana Prenada Media Group, 2010), h. 3
} 
kreativitas anak usia taman kanak-kanak, serta strategi apa yang harus dilakukan oleh guru agar dapat memfasilitasi wujudnya perkembangan kreativitas anak didik.

Menurut Ibn Al-Qayyim Al-Jauziyyah yang dikutip dalam bukunya Siti Khoiriyah mengatakan, "jika terlihat kerusakan pada diri anak-anak, mayoritas penyebabnya adalah bersumber dari orang tuanya". ${ }^{2}$ Dan dijelaskan dalam ayat AlQur'an sebagai berikut:

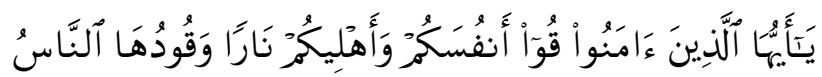

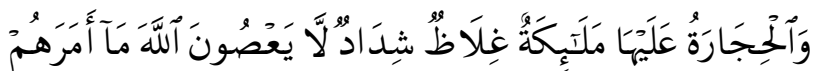



Artinya: "Hai orang-orang yang beriman, peliharalah dirimu dan keluargamu dari api neraka yang bahan bakarnya adalah manusia dan batu; penjaganya malaikat-malaikat yang kasar, keras, dan tidak mendurhakai Allah terhadap apa yang diperintahkan-Nya kepada mereka dan selalu mengerjakan apa yang diperintahkan". (Q.S AlTahrim: 5$)^{3}$

Di dalam pendidikan anak usia dini, orang tua dan guru bukanlah pengajar. Melainkan sebagai pendidik yang mengarahkan, dan sebagai motivator anak didik. Orang tua dan guru diharapkan bisa memberikan stimulasi pada anak, sehingga terjadi proses pembelajaran yang berpusat pada anak. Stimulasi dapat diberikan dengan cara memberikan kesempatan pada anak untuk menjadi kreatif. Biarkan anak dengan bebas melakukan, memegang, menggambar, membentuk, ataupun membuat dengan caranya sendiri dan menguraikan pengalamannya sendiri. Bebaskan daya kreatif anak dengan membiarkan anak menuangkan imajinasinya. Ketika anak mengembangkan keterampilan kreatif, maka anak tersebut juga dapat menghasilkan ide-ide yang inovatif dan jalan keluar dalam menyelesaikan masalah serta meningkatkan kemampuan dalam mengingat sesuatu. Suatu cara yang mampu menyalakan percikan-percikan kreativitas anak, mereka bebaskan menuangkan pikirannya.

\footnotetext{
2 Siti Khorriyatul Khotimah, Perkembangan Anak, (Surabaya:Dakwah Digital Press, 2009), h.47

${ }^{3}$ Al-Qur'an, 66:5
}

Dalam beberapa diskursus psikologi perkembangan, secara umum anak merupakan regenerasi genetis dari hubungan ayah dan ibu yang masih berada dalam usia belum matang. Namun dalam perkembangan sosial dan pendidikannya anak juga merupakan makhluk sosial seperti halnya orang dewasa yakni membutuhkan orang lain untuk dapat membantu mengembangkan kemampuannya. ${ }^{4}$

Dalam bukunya Yeni Rahmawati, dan Euis Kurniati, Munandar sebagai ahli yang meneliti tentang ketrampilan, menyatakan; bahwa ketrampilan dapat di wujudkan melalui kreativitas. ${ }^{5}$ Hal ini sangat penting bagi perkembangan anak-anak karena ketrampilan memberikan kesenangan dan kepuasan pribadi yang sangat besar bagi anak-anak, namun karena sulit diidentifikasikan maka sering kali dianggap tidak penting. Padahal ketrampilan sangat besar peranannya dalam penyesuaian pribadi dan sosial.

Pendidikan ketrampilan merupakan tuntutan kehidupan yang sangat penting. Ketrampilan akan menghasilkan berbagai inovasi dan perkembangan baru dalam suatu kehidupan. Suatu individu dan organisasi yang kreatif akan selalu dibutuhkan oleh lingkungannya, karena mereka dapat mampu memenuhi kebutuhan lingkungan yang terus berubah dan mampu untuk bertahan dalam kompetisi global yang dinamis dan ketat.

Potensi kreatif yang sangat penting tersebut pada dasarnya dimiliki oleh setiap anak. Anak memiliki ciri individu yang kreatif, misalnya: rasa ingin tahu yang besar, senang bertanya, imajinasi yang tinggi, berani menghadapi risiko, senang akan hal-hal yang baru, dan lain sebagainya. Meskipun demikian faktor orang tua, guru di sekolah, dan lingkungan merupakan faktor penting yang sangat mempengaruhi perkembangan kreativitas tersebut.

Berdasarkan penelitian di Harvard University Amerika Serikat dalam bukunya Novan Ardy Wiyani, ternyata kesuksesan seseorang tidak di tentukan semata-mata oleh pengetahuan dan kemampuan teknis (hard skill) saja, tetapi lebih pada kemampuan mengelola diri dan orang lain (soft skill). Penelitian ini mengungkapkan, kesuksesan hanya di tentukan sekitar 20 persen oleh hard skill dan

\footnotetext{
4 Agoes Dariyo, Psikologi Perkembangan Anak, Anak Tiga Tahun Pertama, (Bandung: PT. Refika Aditama, 2007), h. 12.

5 Yeni Rahmawati, Euis Kurniati, Strategi Perkembangan Kreativitas Pada Anak Usia Taman Kanak-Kanak, h. 38
} 
sisanya 80 persen oleh soft skill. Bahkan orang-orang tersukses di dunia bisa berhasil dikarenakan lebih banyak didukung kemampuan soft skill dari pada hard skill. Hal ini mengisyaratkan bahwa mutu pendidikan karakter peserta didik sangat penting untuk di tingkatkan. Soft skill ini merupakan bagian karakter yang harus dibentuk melalui pendidikan mulai tingkat Pendidikan Anak Usia Dini (PAUD) sampai dengan perguruan tinggi. ${ }^{6}$

Pendidikan pra sekolah adalah pendidikan untuk membantu pertumbuhan dan perkembangan jasmani dan rohani anak, di luar lingkungan keluarga sebelum memasuki pendidikan dasar, yang diselenggarakan di jalur pendidikan sekolah atau di jalur pendidikan luar sekolah ${ }^{7}$. Taman Kanak-Kanak (TK) atau Raudlatul Athfal (RA) adalah salah satu bentuk pendidikan pra sekolah yang menyediakan program pendidikan dini bagi anak usia empat tahun sampai memasuki pendidikan dasar.

Tujuan pendidikan nasional adalah mengembangkan potensi peserta didik agar menjadi manusia yang beriman, bertaqwa, kepada Tuhan YME berakhlak mulia, sehat, berilmu, cakap ,kreatif, mandiri dan menjadi warga Negara yang demokratis serta bertanggung jawab. ${ }^{8}$

Ketrampilan merupakan suatu aktivitas dan kemampuan untuk menciptakan sesuatu atau dua kombinasi baru, berdasarkan unsur-unsur yang telah ada sebelumnya menjadi sesuatu yang berarti dan bermanfaat. Ketrampilan kreativitas dapat terwujud di mana saja, kapan saja dan oleh siapa saja tanpa memandang usia maupun tingkat pendidikan tertentu. Menyibukkan diri dengan melakukan halhal yang kreatif sangat bermanfaat dan memberikan kepuasan tersendiri. Maka dengan sendirinya anak dapat mengeluarkan inspirasinya untuk mewujudkan ketrampilan yang mereka inginkan. Dan tidak dipungkiri lagi bahwa ketrampilan atau kreativitas dapat meningkatkan kualitas hidup dan sesuai dengan tujuan pendidikan nasional.

Jadi, kreativitas dan ketrampilan bagi anak-anak bermakna penting sebagai sumber kesenangan dan

\footnotetext{
${ }^{6}$ Novan Ardy Wiyani, Pendidikan Karakter Berbasis Iman Dan Taqwa, (Yokyakarta: Teras 2012), hal.12-13

7 Sardiman, Interaksi Belajar Mengajar Tentang Pendidikan Pra Sekolah (Jakarta: Raja Grafindo 2007), h. 8.

8 Undang-Undang Republik Indonesia No. 20 Tahun 2003

Tentang Sistem Pendidikan Nasional, (Jogjakarta: Bening, 2010), h.17
}

Jurnal Dirasah, Volume 1, Nomor 2, Agustus 2018 kepuasan pribadi, penyesuaian pribadi, sosial, dan kemampuan menyelesaikan masalah. Keberhasilan memupuk kreativitas dan ketrampilan pada masa kanak-kanak, akan mengantarkan mereka menjadi individu dewasa dengan cara berfikir terampil dan kreatif. $^{9}$

\section{Metode Penelitian}

Kehadiran peneliti dalam penelitian kualitatif sangat penting sebab peneliti sebagai human instrument dan dengan teknik pengumpulan data participant observation (Observasi berperan serta) dan in depth Interview (wawancara mendalam), maka peneliti harus berinteraksi dengan sumber data. Dengan demikian peneliti kualitatif harus mengenal betul orang yang memberikan data. ${ }^{10}$

Peneliti sebagai instrumen penelitian dimaksudkan sebagai pewawancara dan pengamat, sebagai pewawancara peneliti akan mewawancarai dewan pengurus dan guru serta para murid atau anak didik dan semua sektor yang berkaitan dengan pendidikan ketrampilan. Sebagai pengamat (observer), peneliti mengamati proses kegiatan pendidikan ketrampilan di Madrasah TK Plus Darul Athfal Sumbersari Kencong Kepung Kediri, dengan menggunakan media bermain, keadaan sarana dan prasarana di Madrasah TK plus Darul Athfal Sumbersari Kencong Kepung Kediri. Jadi selama penelitian ini dilakukan, peneliti bertindak sebagai observer, pengumpul data, penganalisis data dan sekaligus pelapor hasil penelitian. Dalam penelitian kualitatif, kedudukan peneliti adalah sebagai perencana, pelaksana, pengumpul data, penganalisis, penafsir data dan akhirnya pelapor hasil penelitian. ${ }^{11}$ Lokasi tempat penelitian skripsi ini adalah di TK Plus Darul Athfal Sumbersari Kencong Kepung Kediri. Tepatnya berada pada naungan Yayasan Pondok Pesantren Salafiyah Darussalam yang terletak di Dusun Sumbersari Desa Kencong Kecamatan Kepung Kabupaten Kediri Jawa timur.

Sumber data yang diperlukan dalam penelitian ini, terdiri dari data primer dan data skunder. Data

\footnotetext{
${ }^{9}$ Khotimah, Perkembangan Anak, h.71

${ }^{10}$ Sugiyono, Metode Penelitian Kuantitatif, Kualitatif dan $R \&$ $D$, (Bandung: Alfabeta, 2009), h. 11

11 Lexy. J. Moleong, Metode Penelitian Kualitatif, (Bandung; PT Remaja Rosda Karya, 1991),h. 95.
} 
primer adalah data yang banyak digunakan, dan merupakan salah satu ciri penelitian kualitatif. Data ini diperoleh atau bersumber dari informasi, dimana perguruan, pengurus dan anak didik sebagai informannya. Data primer dalam penelitian ini meliputi :

1. Guru TK Plus Darul Athfal

2. Anak didik TK Plus Darul Athfal

3. Program dan jenis-jenis ketrampilan yang diajarkan.

4. Metode-metode pembelajaran.

Data sekunder adalah data yang diterbitkan oleh organisasi yang bukan merupakan pengolahannya. Data sekunder ini digunakan sebagai data pendukung dari data primer. Data ini didapat atau diperoleh dari dokumen-dokumen pondok pesantren yang berupa teori, misalnya: program kerja kepala TK Plus Darul Athfal, hasil penelitian, literatur-literatur yang berhubungan dengan masalah penelitian. Sedangkan data sekunder merupakan data suplemen yang meliputi:

1. Sejarah dan tujuan berdirinya TK di Sumbersari Kencong Kepung Pare Kediri.

2. Sarana dan pra sarana di TK Plus Darul Atfhal Sumber Sari Kencong Kepung Pare Kediri

3. Struktur keperguruan di TK Plus Darul Atfhal Sumber Sari Kencong Kepung Pare Kediri.

4. Foto dan beberapa dokumen yang relevan dengan kegiatan belajar keterampilan.

Analisis data teknik analisis data yang dipergunakan dalam penelitian ini adalah kualitatif deskriptif. Analisis Deskriptif dimaksudkan untuk memberikan deskripsi mengenai subyek penelitian berdasarkan data dari variabel yang diperoleh dari kelompok subyek yang diteliti dan tidak dimaksudkan untuk menguji hipotesis. ${ }^{12}$

Analisis data kualitatif adalah upaya yang dilakukan dengan jalan bekerja dengan data, mengorganisasikan data, memilah-milahnya menjadi satuan yang dapat dikelola, mensistesiskannya, mencari dan menemukan pola, menemukan apa yang

\footnotetext{
12 Syaifuddin Azwar, Metode Penelitian (Jogjakarta: Pustaka Pelajar, 2010).h. 56

${ }^{13}$ Lexy J. Moleong, Metodelogi Penelitian Kualitatif, (Bandung; Remaja Rosdakarya, 2003), h. 248

14 Milles dan Huberman, Analisis Data Kualitatif Tentang Metode-Metode Baru, terj. Tjetjep Rohendi, (Jakarta; UI Press, 1992). h.112.

15 W.J.S. Poerwadarminta, Kamus Umum Bahasa Indonesia, (Jakarta; Balai Pustaka, 1991), cet. II, h. 250.
}

penting dan apa yang dipelajari, dan memutuskan apa yang dapat di ceritakan kepada orang lain. ${ }^{13}$

Peneliti memperhatikan anjuran yang dikemukakan oleh Milles dan Huberman bahwa ada tiga tahapan yang dikerjakan dalam analisis data yaitu : (1). Reduksi Data, (2). Penyajian Data, (3). Penarikan Kesimpulan, ${ }^{14}$

\section{Kajian Pustaka \\ Pendidikan Ketrampilan}

\section{Pengertian Pendidikan Ketrampilan}

Dari segi bahasa, pendidikan dapat diartikan perbuatan (hal, cara, dan sebagainya) mendidik, dan berarti pula pengetahuan tentang mendidik atau pemeliharaan (latihan-latihan dan sebagainya) badan, batin dan sebagainya. ${ }^{15}$ Sebagian pakar menjelaskan bahwa pendidikan berasal dari kata "didik" dengan memberi awalan "pe" dan akhiran "an", dalam arti luas adalah segala pengalaman belajar yang dilalui peserta didik dengan lingkungan dan sepanjang hayat. ${ }^{16}$ Dalam bahasa Arab, para pakar pendidikan pada umumnya menggunakan kata tarbiyah untuk arti pendidikan. Ahmad Fuad Al-Ahwani, Ali Khalil Abu Al-'Ainain, Muhammad Athiyah Al-Abrasyi dan Muhammad Munir Mursyi misalnya menggunakan kata tarbiyah untuk arti pendidikan. ${ }^{17}$

Adapun pengertian pendidikan dari segi istilah, kami ambil dari pengertian yang dinyatakan dalam undang-undang tentang sistem pendidikan nasional (UU RI No.20 Th. 2003), bahwa pendidikan adalah usaha sadar untuk menyiapkan peserta didik melalui kegiatan bimbingan, pengajaran, dan/atau latihan bagi peranannya di masa yang akan datang. ${ }^{18}$

Ki Hajar Dewantara, Bapak Pendidikan mengatakan dalam bukunya Novan Ardy Wiyani bahwa pendidikan berarti daya upaya untuk memajukan pertumbuhan budi pekerti (kekuatan batin, karakter), pikiran (intelect) dan tubuh anak

\footnotetext{
${ }^{16}$ Ramayulis, Ilmu Pendidikan Islam, (Jakarta: Kalam Mulia, 2008), h. 17-18

17 Abuddin Nata, Metodologi Studi Islam, (Jakarta: PT Raja Grafindo Persada, 2007), h. 334.

18, Undang-Undang Republik Indonesia No. 20 Tahun 2003 Tentang Sistem Pendidikan Nasional, (Jogjakarta: Bening, 2010), h.17.
} 
yang antara satu dan lainnya saling berhubungan agar dapat memajukan kesempurnaan hidup, yakni kehidupan dan penghidupan anak-anak yang kita didik selaras dengan dunianya. ${ }^{19}$

Jadi, dapat disimpulkan bahwa pendidikan adalah usaha atau proses yang ditujukan untuk membina kualitas sumber daya manusia seutuhnya agar ia dapat melakukan perannya dalam kehidupan secara fungsional dan optimal. Dalam ayat Al-Qur'an disebutkan bahwa peserta didik berpotensi sebagai subjek didik yang berarti harus dididik, ${ }^{20}$ hal tersebut dijelaskan dalam Surat Al-A'rof: 179:

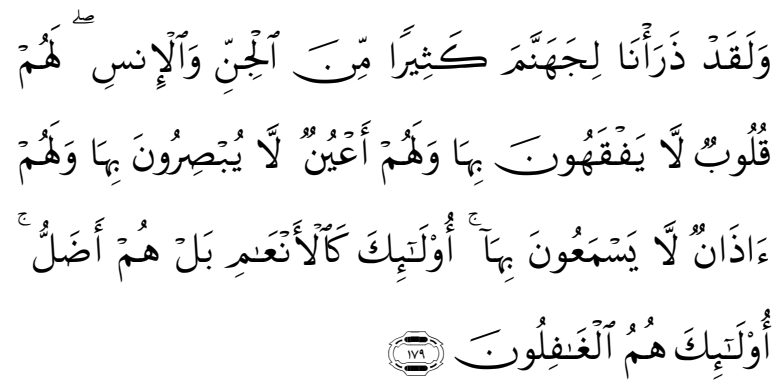

Artinya: "Dan Sesungguhnya Kami jadikan untuk (isi neraka Jahannam) kebanyakan dari jin dan manusia, mereka mempunyai hati, tetapi tidak dipergunakannya untuk memahami (ayat-ayat Allah) dan mereka mempunyai mata (tetapi) tidak dipergunakannya untuk melihat (tanda-tanda kekuasaan Allah), dan mereka mempunyai telinga (tetapi) tidak dipergunakannya untuk mendengar (ayat-ayat Allah). mereka itu sebagai binatang ternak, bahkan mereka lebih sesat lagi. mereka Itulah orang-orang yang lalai”. (Q.S Al-A'rof: $179)^{21}$

Menurut John Dewey yang sudah diterjemahkan oleh Ahmad Muthohir, dijelaskan bahwa hakikat pendidikan meliputi seluruh aspek kehidupan. Pendidikan merupakan kebutuhan hidup asasi (anecessity of life), fungsi sosial (social function), pengarah, pengendali dan pembimbing (direction, control and guidance), konservatif (mewariskan dan mempertahankan

\footnotetext{
${ }^{19}$ Novan Ardy Wiyani, Pendidikan Karakter Berbasis Iman Dan Taqwa, (Yokyakarta: Teras 2012), hal.12

${ }^{20}$ Moh. Fauziddin, Novi Nitya Santi, Pekembangan Peserta Didik, Pada Anak Usia Dasar, (t.t.p., t.p.: 2012), h. 14

21 Al-Qur'an, 7:179
}

cita-cita suatu kelompok), progresif (membekali dan mengembangkan pengetahuan nilai dan ketrampilan, sehingga mampu menghadapi tantangan hidup). ${ }^{22}$ Sedangkan pengertian ketrampilan berasal dari kata "terampil" yang bermakna cakap dalam menyelesaikan tugas, mampu dan cekatan. ${ }^{23}$

Pendidikan ketrampilan yang dikembangkan di TK Plus Darul Athfal Sumbersari Kencong Kepung Kediri untuk kepentingan dan kebutuhan anak didik sendiri, sebagai modal untuk menjadi manusia yang trampil bersemangat wiraswasta (entrepreneurship) dan sekaligus menunjang pembangunan masyarakat yang kreatif. Dengan menggunakan media bermain lebih mudah guru dalam membentuk imajinasi anak didik melalui pendidikan ketrampilan atau kreativitas.

Ada persyaratan utama dalam mengunakan media bermain sebagai pengembangan ketrampilan yaitu:

a. Persyaratan Edukatif (mendidik)

1) Alat permainan memberi peluang kepada anak untuk mencoba alat permainan dengan bebas, sesuai dengan tingkat perkembangan, kemampuan dan minatnya.

2) Alat permainan dibuat sedemikian rupa, sehingga anak dapat memperbaiki kesalahan-kesalahan yang mungkin dibuatnya.

3) Alat permainan dapat memberi kepuasan bagi si pemain yaitu anak pra sekolah, karna anak merasa bisa melakukan ketrampilan setelah menggunakan daya pikirnya. Keberhasilan ini biasanya akan Imembangkitkan semangat anak untuk mengulagi permainan atau mencoba-coba dengan alat-alat permainan lainnya.

b. Pesyaratan teknik

1) Alat permaina harus menarik dilihat dari sudut warna, bentuk dan rupa serta mudah digunakan.

2) Alat permainan aman digunakan anakanak, yang bentuknya tidak tajam atau

\footnotetext{
${ }^{22}$ Ahmad Muthohir, Ideologi Pendidikan Pesantren (Pesantren di Tengah Arus Ideologi-ideologi Pendidikan), (Semarang: Pustaka Rizki Putra, 2007). h. 2.

${ }^{23}$ Wahid Zaini, Dunia Pemikiran Kaum Santri, (Yogyakarta: LKPSM, 1995), h. 53.
} 
runcing, tidak terlalu kecil, sehingga tidak mudah tertelan oleh anak, tidak mengandung racun, sehingga tidak menggangu kesehatan dan kehidupan anak. $^{24}$

Dengan pembuatan alat permainan sebagai media pendidikan hal ini diharapkan dapat memberikan manfaat untuk menjadi lebih kreatif dalam mengembangkan dan membentuk imajinasi anak didik.

Adapun proses kreatif hanya akan terjadi jika dibangkitkan melalui masalah yang memacu pada lima macam prilaku kreatif, sebagaimana yang dipaparkan oleh parnes dalam bukunya Yeni Rahmawati dan Euis Kurniati ${ }^{25}$ sebagai berikut:

a. Fluency (kelancaran), yaitu kemampuan mengemukakan ide yang serupa untuk memecahkan suatu masalah.

b. Flexibility (keluwesan), yaitu kemampuan untuk menghasilkan berbagai macam ide guna memecahkan suatu masalah diluar katagori biasa.

c. Originality (keaslian), yaitu kemampuan memberikan respons yang unik atau luar biasa.

d. Elaboration (keterperincian), yaitu kemampuan menyatakan pengarahan ide secara terperinci untuk mewujudkan ide menjadi kenyataan.

e. Sensitivity (kepekaan), yaitu kepekaan menangkap dan menghasilkan masalah sebagai tanggapan terhadap suatu situasi.

Disinilah pentingnya kehadiran guru sebagai pembimbing yang akan membantu anak didik menyeimbangkan perkembangangan kepribadiannya, sehingga anak kreatif dapat berkembang optimal tidak hanya perkembangan inteligensinya tetapi juga perkembangan sosial dan emosinya. Untuk mempertahankan daya trampil kreatif, para pendidik harus memperhatikan sifat natural anak yang sangat menunjang tumbuhnya jiwa trampil kreatif. Sifatsifat natural yang mendasar inilah yang harus

24 http://childrengarden. Wardpress. Co /2010/04/02. Tahap Perkembangan Anak Dalam Menulis, di akses tanggal 15 April 2011.

${ }^{25}$ Yeni Rahmawati dan Euis Kurniati, Strategi Perkembangan Kreativitas Pada Anak Usia Taman Kanak-Kanak, (Jakarta:Kencana Prenada Media Group, 2010), h.14-15. senantiasa di pupuk dan dikembangkan sehingga sifat kreatif mereka tidak hilang. ${ }^{26}$

\section{Tujuan pendidikan ketrampilan}

Kreatifitas adalah bentuk dari ketrampilan yang harus dikembangkan mulai dari sejak dini. Potensi kreativitas alami yang dimiliki anak didik akan senantiasa membutuhkan aktifitas yang syaratnya dengan ide kreatif. Maka secara natural anak memiliki kemampuan untuk mempelajari sesuatu menurut caranya sendiri. Ketrampilan yang diperlukan bagi kehidupan sehari-hari dapat terbagi dalam beberapa kategori yang tidak hanya bercorak ketrampilan saja, akan tetapi juga mengandung aspek pengetahuan dan sikap, yakni:

a) Ketrampilan untuk mencari nafkah dan rangka sistem ekonomi suatu negara.

b) Ketrampilan untuk mengembangkan masyarakat.

c) Ketrampilan untuk menyumbang kepada kesejahteraan umum. ${ }^{27}$

Hal ini menggabungkan humanisme dengan pendidikan kewarganegaraan dan pendidikan pembangunan nasional.

\section{Jenis pendidikan ketrampilan}

Banyak jenis pendidikan ketrampilan yang dapat dikembangkan di TK Plus Darul Athfal Sumbersari Kencong Kepung Kediri. Bahkan beberapa pendidikan taman kanak-kanak menjadikan kegiatan ketrampilan sebagai trademark-nya. Di antaranya Pendidikan ketrampilan melalui imajinasi, hasta karya, eksplorasi, eksperimen, proyek, musik dan bahasa. $^{28}$

\section{Teori Pendidikan Ketrampilan ${ }^{29}$}

Cara yang sudah diterapkan dalam pendidikan ketrampilan di TK Plus Darul Athfal Sumbersari Kencong Kepung Kediri, dalam pendidikan ketrampilan pada anak didik adalah teori pendidikan ketrampilan melalui imajinasi, eksplorasi, musik dan bahasa.

Pada masa anak berusia 1 tahun ke atas, pada umunnya anak sudah mulai bisa berjalan meskipun belum normal. Saat ini, yang merupakan tonggak

\footnotetext{
${ }^{26}$ Ibid., h.38

${ }^{27}$ M. Sulthon masyhud, et.al., Manajemen Pondok Pesantren, (Jakarta; Diva Pustaka, 2003), 88.

28 Dokumentasi, Periode 2009-2010, BPM (Buku Pedoman Mengajar), Tk Plus Darul Athfal, Sumbersari.

29 Dokumentasi, Periode 2012-2013, BPM (Buku Pedoman Mengajar), Tk Plus Darul Athfal, Sumbersari.
} 
perkembangan kognitif ini adalah perkembangan motorik kasar yang penting bagi usia anak-anak, pada priode ini sebaiknya di mulai dengan permainan yang mengasyikkan.

Perkembangan kognitif bisa di ketahui ketika anak itu bisa berjalan, berlari, melompat. Dalam perkembangan kogitif ini bola juga dapat di buat media pendidikan. Misalnya, untuk mengenalkan konsep bulat dan tidaknya, besar dan kecilnya bola, yang merupakan salah satu pengenalan bentuk geometris. Seperti: lihat bola itu bisa menggelinding karena bola itu bulat, kalau yang bentuknya kotak itu seperti mainan milik adek itu tidak bisa menggelinding. Keberagaman warna juga bisa di perkenalkan melalui bola, berikanlah anak dengan bola yang wara-warni, lalu suruh memilih mana bola yang merah, dan mana bola kuning, meskipun terkadang anak masih sering keliru. Akan tetapi pembelajaran ini harus sering di lakukan karena pembelajaran ini akan membuatnya lebih memahami tentang warna.

Semua hasil yang dilakukan oleh orang tua itu tidak akan di dapat secara instan. Akan tetapi, dengan seringnya anak di kenalkan, maka lambat laun anak akan memahaminya. Sedangkan cara mengenalnyapun tidak boleh dengan paksaan, harus dengan lemah lembut, santai dan bisa sambil bemain. Dengan demikian apa yang kita lakukan akan bermanfaat untuk anak dikemudian hari, dan itu juga baik bagi pertumbuhan kepribadiaanya. Karna anak akan merasa bahwa ia di besarkan dengan kasih saying yang tulus. ${ }^{30}$

\section{Membentuk Imajinasi}

Membentuk imajinasi adalah kemampuan berfikir atau mengembangkan ketrampilan melalui media bermainat. Mengunakan media bermain tentu sangat menyenangkan bagi si kecil sekaligus dapat menstimulasi kecerdasan. Umur 6 tahun pertama kehidupan si kecil harus banyak diisi dengan bermain, sebab proses tumbuh kembang fisik dan otak yang paling optimal terjadi di usia tersebut. ${ }^{31}$

Dengan mengunakan media bermain sebagai alat pengembangan dan pembentukan imajinasi anak didik ini lebih mudah untuk mewujudkan

30 Maimunah Hasan, Pendidikan Anak Usia Dini (Bandung: Diva Prees 2009), h, 95 ketrampilan yang ada dilembaga TK Plus Darul Athfal Sumbersari Kencong Kepung Kediri. Karena dengan kemampuan berimajinasi anak memiliki kesempatan untuk menciptakan suatu objek tanpa didukung oleh data yang nyata. Dengan imajinasi, anak bebas memikirkan sesuatu tanpa dibatasi oleh aturan yang baku, yang mungkin tidak sesuai dengan keinginannya dan cenderung membosankan. Anakanak yang diberi kesempatan untuk berimajinasi lewat bermain atau aktivitas lain, akan lebih mudah memunculkan potensi-potensi kreatifnya. Secara umum, kemampuan imajinasi ini diperlukan bagi anak untuk dapat menjadi lebih ceria dan bersikap positif dalam menikmati hidup.

Dengan adanya kemampuan ini anak akan dapat mengembangkan berbagai kemampuan positif yang lain. Misalnya ia dapat mengembangkan kemampuan bereksperimen, sehingga timbul keinginan untuk menciptakan dan membuat program sendiri. Anak-anak yang memiliki kemampuan imajinasi yang baik akan dapat mengisi waktunya sendiri tanpa banyak bantuan dari orang lain. Ia tidak mudah bosan, karena selalu ada ide-ide yang memotivasinya untuk berkreasi. Selain itu dengan kemampuan imajinasi, anak juga akan memiliki rasa humor yang membantunya dalam merilex ketegangan-ketegangan yang dialaminya. Kemampuan lain yang juga dapat dikembangkan adalah ketrampilan dalam mengenal dan memahami tingkah laku orang lain, ketrampilan berbahasa dan mengarang cerita.

Salah satu pendekatan yang dilakukan pada anak usia dini untuk merangsang dan mengembangkan ketrampilan anak adalah dengan mengunakan kegiatan bermain dan belajar, yang dilakukan di lingkungannya dengan mengunakan sarana, alat permainan yang edukatif dan memanfaatkan berbagai sumber belajar dengan menggunakan media permainan flashcard, yaitu media pembelajaran dalam bentuk kartu bergambar yang didalamnya terdapat tulisan, gambar, atau tanda pengganti bilangan yang bervariasi, ini juga mempermudah anak-anak dalam mengembangkan ketrampilannya.

\footnotetext{
${ }^{31}$ Rose Mini., "Asah Kecerdasan Majemuk Si Kecil Dengan Morinaga MI Playolan” jawa pos, 26 April 2015, h.5
} 
Islam menjelaskan bahwa manusia adalah makhluk yang terbaik, karna mendapatkan karunia berupa akal pikiran yang tidak diberikan kepada makhluk selain manusia. ${ }^{32}$ Dengan akal dan fikiran tersebut manusia mampu mengembangkan potensinya. Sesuai dalam firman-Nya dalam AlQur'an:



Artinya: "Sesungguhnya Kami telah menciptakan manusia dalam bentuk yang sebaik-baiknya". (Q.S. At-Tiin Ayat: 4). ${ }^{33}$

Manusia dibekali potensi berupa inteligensi yang merupakan kemampuan yang dibawa sejak lahir. Kemampuan inteligensi ini bersifat umum, yang dapat menyesuaikan diri terhadap situasi atau masalah yang bersifat umum, seperti; berfikir mekanis, matematis, memahami, mengingat bahasa, dan sebagainya. ${ }^{34}$ Menurut pendapat William Stern yang dikutip dalam bukunya Abdul Rohman Sholeh menyatakan "inteligensi adalah kemampuan atau kesangupan jiwa untuk dapat menyesuaikan diri dengan cepat dan tepat dalam suatu situasi yang mengunakan alat-alat berfikir yang sesuai dengan tujuannya. ${ }^{35}$ Seorang guru harus mengetahui kemampuan-kemampuan yang dimilki anak didiknya, dengan ini guru akan lebih mudah dalam menyampaikan pendidikan ketrampilan yang sesuai dengan anak didiknya. Yang terpenting dalam mendidik anak didik adalah memahami bukan sabar, memahami anak didik sebagai berikut:

1. Anak sebagai individu yang unik

2. Anak memiliki retme perkembangan yang berbeda

3. Anak sebagai pelaku utama

4. Anak sebagai teman bekerjasama

5. Anak sebagai komunikator

6. Anak perlu berkembang menjadi manusia yang mudah menyesuaikan diri (adaptable) dan memahami diri serta lingkungannya (undestarding). ${ }^{36}$

\footnotetext{
${ }^{32}$ Moh. Fauziddin dan Santi, Pekembangan Peserta Didik, Pada Anak Usia Dasar, (t.t.p., t.p.: 2012), h. 12

${ }^{33}$ Al-Qur'an, 95:4

34 Abdul Rahman Sholeh, Psikologi, Suatu Pengantar Dalam Perspektif Islam, (Jakarta: Kencana,2008), h. 251

${ }^{35}$ Ibid, h. 253
}

Melibatkan peserta didik untuk belajar melalui aktifitas, hal ini merupakan pilar penting dalam mengonstruksi pengetahuan, perasaan, kemauan, dan ketrampilan. Dalam bukunya Muhammad Yaumi, Nurdin Ibrahim yang dikutib Dewantara menyatakan "aktifitas yang telah disebutkan merupakan istilah budi pekerti yang merujuk pada kekuatan batin, karakter, intelektual (pikiran), dan kekuatan tubuh (jasad), atau membangun manusia seutuhnya. Dengan demikian, pilar-pilar pendidikan adalah belajar untuk mengetahui (learning to know), belajar untuk melakukan pekerjaan (learning to do), belajar untuk hidup bersama satu sama lain secara kolaboratif, rukun, dan damai (learning to live together), dan belajar untuk menjadi diri sendiri (learning to be). Para pakar di indonesia menambahkan satu pilar, yakni belajar mengabdi (learning to worship) kepada yang maha kuasa. ${ }^{37}$

Perguruan Di lembaga TK Plus Darul Athfal Sumbersari Kencong Kepung Kediri, mengunakan media bermain sebagai objek dalam pembentukan imajinasi anak didik. Janice Beaty menyatakan dalam bukunya Yeni Rahmawati dan Euis Kurniati bahwa; imajinasi bagi anak adalah kemampuan untuk melakukan fantasi yang mereka buat. Kebanyakan anak berusia tujuh tahun banyak melakukan hal tersebut. ${ }^{38}$ Menurut kamus bahasa indonesia, imajinasi adalah daya pikir untuk membayangkan (di angan-angan) atau menciptakan gambar-gambar (lukisan, karangan dan sebagainya) kejadian, berdasarkan kenyataan atau pengalaman seseorang. Ungkapan seperti "seandainya aku menjadi seorang astronot," atau "seandainya aku bisa terbang dan tinggal di atas awan" ini merupakan contoh dari imajinasi anak.

\section{Pembahasan Temuan Penelitian}

Pada penelitian ini peneliti akan mengkaji lebih dalam mengenai temuan penelitian yang diperoleh di lapangan. Baik melalui observasi, wawancara, dan foto. Seperti halnya sebuah lembaga pendidikan yang lainnya, di TK Plus Darul Athfal ini juga menyediakan wadah untuk ikut serta dalam

\footnotetext{
36 Dwi Astutik, Diklat Kurikulum 13 Tentang Pendidikan Anak Usia Dini, Kediri, tgl 27-03-2013

37 Muhammad Yaumi dan Nurdin Ibrahim, Pembelajaran Berbasis, Kecerdasan Jamak (Multiple Intelligences), (T.t.p., Kencana Prenada Media Group: 2013), h. 1

${ }^{38}$ Yeni Rahmawati dan Euis Kurniati, Strategi Perkembangan, h.53-54.
}

Jurnal Dirasah, Volume 1, Nomor 2, Agustus 2018 
menyukseskan program mencetak anak didik yang terampil kreatif dan mempunyai budi pekerti yang baik. Lembaga ini setiap tahun selalu mengikut sertakan anak didiknya lomba antar lembaga, hal ini menjadi motivasi bagi anak-anak untuk bisa selalu mengeluarkan ide-ide baru dan selalu menjadi anak yang kreatif.

\section{Implementasi pendidikan ketrampilan yang ada di TK Plus Darul Athfal Sumbersari Kencong Kepung Kediri}

Pendidikan ketrampilan ini dimaksudkan untuk membekali anak didik dengan berbagai ketrampilan yang diharapkan nantinya siswa dapat mengembangkan ketrampilan-ketrampilan tersebut ketika mereka dewasa nanti dan mengabdi pada masyarakat, juga sebagai sarana untuk memenuhi kebutuhan ekonomi. ${ }^{39}$

Sebagai realisasinya, jenis pendidikan ketrampilan yang ada di TK Plus Darul Athfal Sumbersari Kencong Kepung Kediri ini antara lain:

pendidikan ketrampilan melalui imajinasi

Pendidikan ketrampilan melalui imajinasi diajarkan di TK Plus Darul Athfal ini berguna untuk memicu pengembangan kreativitas anak, guru dan anak didik diharapkan mampu mengembangakan ide dan model-modelnya sendiri, ini dilakukan dengan tanpa tekanan atau paksaan dari lingkungan dengan tujuan agar mereka dapat membentuk pola pikir yang kreatif. Ketrampilan ini dapat siswa apresiasikan melalui, mengikuti lomba yang diadakan oleh lembaga-lembaga lain. Guru memberikan semangat belajar dengan cara, siapa yang bisa mengambar atau mewarnai bisa membuat kreatifitas yang baik dan bagus maka kalian akan di ikutkan lomba dan ikut jalan-jalan.

Lembaga ini setiap tahunya mengajak anak didiknya untuk mengikuti lomba ketrampilan sejumlah 80 siswa dengan berbagai macam bentuk ketrampilan yang mereka buat seperti: mewarnai, mengambar, membuat karya seni dll. Metode yang digunakan oleh guru adalah bermain sambil belajar, belajar dengan bermain ini mempermudah anak didik untuk bisa mengikuti pendidikan ketrampilan dengan tanpa adanya paksaan dari guru maupun lingkungan.

\footnotetext{
${ }^{39}$ Wawancara Dengan Ibu Naily Syafa'ah, Selaku guru TK Plus Darul Athfal , Pada Tanggal 06 Mei 2015. Jam 10.15-10.45 WIB.
}

Dengan bermain anak-anak bisa leluasa untuk mengeluarkan imajinasinya, guru cukup memberikan contoh dan pengarahan saja.

Pendidikan ketrampilan melalui eksplorasi

Pendidikan Ketrampilan Melalui Eksplorasi merupakan salah satu dunia anak-anak dalam bermain di usia ini mereka lebih senag bermain. Kegiatan ini dapat membantu terbentuknya sikap dan rasa ingin tahu yang tinggi. Rasa ingin tahu yang besar ini sangat dibutuhkan dalam pengembangan kreatifitas anak-anak.

Metode yang digunakan oleh guru adalah setiap satu minggu 2 kali anak-anak di ajak belajar atau bermain di luar kelas dengan tujuan memberikan suasana baru pada anak-anak agar mereka tidak merasakan jenuh dalam belajar. Dalam setiap proses belajar mengajar memang tidak pernah terlepas dari sebuah permainan, begitu juga pada materi agama. Setelah 10 menit yang pertama digunakan untuk mengenal agama dengan di iringgi menyanyi, baru kemudian bermain, seperti permainan 'aneka gelembung sabun, guru mempersiapkan alat-alatnya ya'ni air sabun, dan kawat anak-anak dapat membentuk kawat dengan berbagai bentuk (misalnya lingkaran kecil, besar, segitiga, bulat lonjong d1l.). sehingga anak-anak dapat menghasilkan bentuk gelembung yang beragam. Atau permainan 'kucing \& tikus', dimana anak-anak yang dapat menjawab pertanyaan guru seputar agama maka, salah satu dari siswa, dapat memainkan peran tikus/kucing, dan guru yang lain bertugas menjadi pagar dengan cara bergandengan tangan secara melingkar dan rapat. ${ }^{40}$ Permainan ini sangat bermanfaat baik sekali untuk pembentukan imajinasi anak-anak.

Tujuan dari pendidikan ketrampilan melalui Eksplorasi di taman kanak-kanak adalah:

1) Untuk menumbuhkan rasa keingintahuan tentang sesuatu yang anak baru kenal.

2) Untuk memperjelas konsep dan ketrampilan yang telah dimiliki anak didik.

3) Untuk memperoleh pengetahuan tentang bagaimana memahami lingkungan yang ada di sekitar serta bagaimana cara memanfaatkannya.

\footnotetext{
${ }^{40}$ Hasil Observasi Di Kelas TK Plus Darul Athfal, Tanggal 2 Mei 2014 jam 08.00-09.00 WIB.
} 


\section{Pendidikan ketrampilan melalui eksperimen}

Pendidikan Ketrampilan Melalui Eksperimen yang ada di TK Plus Darul Athfal Sumbersari Kencong Kepung Kediri ini bertujuan untuk memicu munculnya kreativitas anak, karena pada awal pengembangan kreativitas, anak membutuhkan iklim pembelajaran yang kondusif dan merangsang rasa ingin tahu anak. Setelah sikap ini terbentuk, maka pada tahap berikutnya anak bisa mengembangkan aktivitasnya dan menemukan gagasan baru yang kreatif .

Metode yang digunakan oleh guru TK Plus Darul Athfal adalah setiap satu minggu 2 kali, selang seling dengan kegiatan Eksplorasi anak-anak di ajak belajar Ketrampilan Melalui Eksperimen, guru hanya memberikan contoh, semisal eksperimen benda yang bisa terapung dan tengelam, (besi dan kertas atau kapas yang tengelam yang mana?). Atau jika air di campuri garam kemudian dimasuki telur apa yang akan terjadi dengan eksperimen uji coba ini. Anakanak akan mencoba, Dengan begini suasana kelas akan hidup dan tidak membosankan. ${ }^{41}$

Pendidikan ketrampilan melalui musik

Pendidikan ketrampilan melalui musik merupakan salah satu dunia anak-anak dengan bernyanyi akan lebih mudah anak-anak menyerap materi yang di sampaikan oleh guru, karena di usia 2-7 tahun anak gemar-gemarnya menyanyi. Guru TK Plus Darul Athfal menggunakan metode menyanyi sebagai salah satu alat untuk bisa mengajak anakanak belajar, dan agar mereka juga dengan mudah menyerap materi yang di sampaikan guru.

Tidak semua orang mempunyai bakat menyanyi Sedangkan cara agar anak itu dapat mengeluarkan bakatnya dengan baik, salah satunya ialah dengan cara menanamkan rasa percaya diri pada anak, karena apabila anak itu tidak di sertai rasa percaya diri, maka ia akan menjadi anak yang penakut, pendiam, dan sering minder bila di hadapkan dengan sesuatu yang lebih besar, sering malu bila harus di tunjuk dan maju kedepan. Potensi manusia untuk menjadi sukses adalah rasa percaya diri yang nantinya akan memberikan kesiapan anak

\footnotetext{
41 Hasil Observasi Di Kelas TK B, Tanggal 06 Mei 2015 Jam 09.30-10 .00 WIB.

${ }^{42}$ Hasil Observasi Di Kelas Tk A, Tanggal 7 Mei 2014 jam 08.00-09.00 WIB.

${ }^{43}$ Hasil Observasi Di Kelas Tk B, Tanggal 7 Mei 2014 jam 09.00-09.30 WIB.
}

untuk bisa belajar mandiri, itu bisa dilakukan dengan cara memberi tugas rumah atau sering ditunjuk kedepan oleh guru untuk memimpin temantemannya berdo'a mau belajar.

\section{Pendidikan ketrampilan melalui bahasa}

Pendidikan ketrampilan melalui bahasa diajarkan di TK Plus Darul Athfal ini berguna agar anak didik bisa pintar dalam berbagai bahasa dan ini membutuhkan tahapan-tahapan awal agar bisa diterima pada anak-anak dan anak-anak tidak merasa kesulitan. Terutama guru mengenalkan satu persatunya huruf, dengan di ulang-ulang terus sampai anak-anak bisa dan hafal baru guru bisa meneruskan huruf selanjutnya. Sekitar 10 menit sebelum mau pulang guru memberi pertanyaan atau mengulang huruf-huruf yang diajarkan tadi, dengan begini murid lebih mudah menerima dan menghafal ini dilakukan di kelas TK A. ${ }^{42}$ Sedangkan di kelas TK B ini berbeda lagi yakni dengan cara membaca satu kata-satu kata, jika mereka sudah bisa, maka gurung menyambung dengan membentuk sebuah kalimat. $^{43}$

Guru-guru TK Plus Darul Athfal ini juga mengunakan metode cepat membaca, adalah dengan cara sebagai berikut;

1) Menyanyi, dengan menyanyi akan menumbuhkan rasa semangat bagi para siswa. Dengan menggunakan metode bernyanyi ini akan membangktkan rasa semangat belajar siswa, sehingga dapat dicapai pembelajaran yang lebih banyak, dan cepat di serap oleh para siswa. ${ }^{44}$

2) Bercerita dongeng-dongeng yang islami. Ada yang menyatakan bahwa cerita adalah merupakan metode pendidikan yang di tempuh oleh Rasulullah saw dalam mendidik generasi muda dari kalangan para sahabat r.a. menurut beliau, para ahli pendidikan dan psikolog bersepakat bahwa kisah dan cerita ringan yang memberikan motivasi dan dan metode ini telah di tempuh oleh Rasulullah saw dalam pendidikannya. Oleh karena itu Allah memerintahkan Rasulullah saw agar menceritakan kisah-kisah kepada para sahabat beliau r.a. baik yang tua maupun yang

\footnotetext{
${ }^{44}$ Moch.Saikhuni Luthfi, Implementasi Pembelajara Al-Qur'an Melalui Metode Jibril Bagi Santri Tafidzhul Qur'an Pon-Pes Bidayatul Hidayah, Mojogeneng Jatirejo Mojokerto, (September 2008), h, 31.
} 
muda. ${ }^{45}$ "...maka ceritakanlah (kepada mereka) kisah-kisah itu agar mereka berfikir”. (QS. AlAraf 8: ayat 176) ${ }^{46}$

Untuk dapat cepat membaca dengan baik, semuanya membutuhkan teknik yang bisa di gunakan. Semuanya saling terkait, tidak ada yang berdiri sendiri, misalnya membaca dengan menggunakan sistem gambar bercerita, disitu juga ada sistem mewarnai gambar, dan juga membaca, juga sistem cerita-cerita yang menarik untuk membantu dan membayangkan gambar yang dilihatnya. ${ }^{47}$

Salah satu Implementasi Pendidikan Ketrampilan Dalam Membentuk Imajinasi Anak Didik di Tk Plus Darul Athfal Sumbersari Kencong Kepung Kediri, adalah dengan menerapkan setiap harinya mengunakan cara yang sering di gunakan oleh para guru TK Plus Darul Athfal, seperti bermain dan belajar, belajar dengan bermain, mendongeng, eksperimen, dan juga bernyanyi ini mempermudah para murid untuk mengikuti pendidikan ketrampilan dengan tanpa paksaan dari sekolahan maupun lingkungan.

Kemampuan yang dimiliki oleh guru-guru TK Plus darul Athfal ini tidak kesemuanya membidangi pendidikan ketrampilan, sehingga para guru diwajibkan untuk mengikuti diklat atau seminar ketrampilan. Hal ini ternyata juga ada nilai positif untuk para guru, dan para guru juga termotivasi untuk mempelajari pendidikan ketrampilan ini. Dan ajang bagi santri untuk mengasah jiwa ketrampilan dan secara tidak langsung usaha-usaha ini juga berperan dalam peningkatan kualitas pendidikan di TK Plus Darul Athfal Sumbersari Kencong Kepung Kediri. $^{48}$

Faktor pendukung dalam membentuk imajinasi anak didik di TK Plus Darul Athfal Sumbersari Kepung Kediri.

Berdasarkan pengamatan peneliti faktor pendukung Pendidikan Ketrampilan Dalam Membentuk Imajinasi Anak Didik di TK Plus Darul

\footnotetext{
${ }^{45}$ Syamsudin H.E, “Konsep Pendidikan Agama Islam”, Ta'lim Pendidikan Agama Islam (Januari,2009), h, 67.

${ }^{46}$ al-Qur'an 8: 176.

${ }^{47}$ Ahmad Musta'in Syafi'i dkk, Al-Asma Al-Husna, cara belajar cepat abad 21metode hanifida, (Jombang: CV. Percetakn Fajar 2009), h, 21.
}

Athfal Sumbersari Kepung Kediri, yang sudah terbiasa di terapkan menggunakan proses mengajar dengan berbagai variasi, dengan adanya metode bervariasi tersebut pendidik ketrampilan tinggal mengembangkan apalagi di dukung dengan sarana dan prasarana yang cukup memadai, serta dukungan dari guru-guru yang lain di beri kebebasan untuk berkreativitas dan berinovasi dalam pembelajaran, sehingga guru di tuntut untuk menjadikan ling belajar dan sumber belajar yang menarik dan menyenangkan bagi anak didik.

Ditambah lagi dengan alat permainan yang diberikan oleh dinas lembaga pendidikan setiap dua bulan sekali, sehingga ini juga membantu lembaga TK Plus Darul Athfal dalam memberikan pendidikan ketrampilan. Dan juga kerja samanya para guru dengan wali murid yang juga menghendakkan anakanaknya untuk menjadi orang yang pintar dan berbudi baik dan kretaif. ${ }^{49}$

Untuk penghambat pendidikan ketrampilan dalam membentuk imajinasi anak didik di TK Plus Darul Athfal Sumbersari Kepung Kediri ini adalah kurangnya kesiapan mental peserta didik yang masih belum mau berpisah dengan orang tuanya, menangis ketika di tinggal orang tua, dan kurang luasnya area di dalam kelas karena banyaknya peserta didik sehingga anak-anak kurang.

\section{Kesimpulan}

Berdasarkan hasil riset dan analisa data yang diperoleh selama penelitian dengan judul " Implementasi Pendidikan Ketrampilan Dalam Membentuk Imajinasi Anak Didik di TK Plus Darul Athfal Sumbersari Kencong Kepung Kediri ", dapat diambil beberapa kesimpulan sebagai berikut :

1. Implementasi Pendidikan Ketrampilan Yang Ada di TK Plus Darul Athfal Sumbersari Kencong Kepung Kediri ialah Pendidikan ketrampilan melalui imajinasi, eksplorasi, eksperimen, musik dan bahasa

Ketrampilan diatas menjadi bagian dari upaya untuk memudahkan seseorang di dalam

\footnotetext{
${ }^{48}$ Hasil Observasi Peneliti di Lapangan, di TK Plus Darul Athfal Sumbersari Kencong Kepung Kediri, Rabu, 13 Mei 2015 jam: 09.00-10.00 WIB.

${ }^{49}$ Wawancara Dengan Siti Sofiyah Salah Satu Wali Murid AnakAnak TK Plus Darul Atfhal, Pada Tanggal, 07 Mei 2015 jam 08.00-08.30 WIB.
} 
mengembangkan dan membetuk pola pikir yang kreatif dan mempunyai imajinasi yang tinggi, dengan ketrampilan ini manusia dapat memenuhi kebutuhan hidup dan memajukan produk negara kita sendiri.

2. Faktor Pendukung Pendidikan Ketrampilan Dalam Membentuk Imajinasi Anak Didik di TK Plus Darul Athfal Sumbersari Kencong Kepung Kediri ialah tersedianya alat-alat permainan, adannya guru-guru yang mampu di bidang ketrampilan. Sedangkan faktor penghambat ketrampilan yaitu kesiapan mental peserta didik yang masih belum mau berpisah dengan orang tuanya, menangis ketika di tinggal orang tua, dan kurang luasnya area di dalam kelas karena banyaknya peserta didik sehingga anak-anak kurang leluasa dalam belajar dan bermain.

\section{Daftar Pustaka}

Arikunto, Suharsimi. Prosedur Penelitian Suatu Pendekatan Praktik. Jakarta : PT Rineka Cipta, 2006.

Audifax. Reseach pengantar untuk "MencariUlang" Metode Penelitian dalam Psikologi". Yogyakarta : Jalasutra, 2008.

Astutik Dwi, Diklat Kurikulum 13 Tentang Pendidikan Anak Usia Dini, Kediri, tgl 27-032013.

Dariyo, Agoes. Psikologi Perkembangan Anak, Anak Tiga Tahun Pertama, Bandung: PT. Refika Aditama, 2007.

Dokumentasi. Preode 2009-2010. BPM Buku Pedoman Mengajar. Tk Plus Darul Athfal, Sumbersari.

Dokumentasi. BPK Buku Panduan Kerja.MIDAMAHISD, Periode 2014-2016 M.

Dokumentasi. BPM Buku Pedoman Mengajar. Tk Plus Darul Athfal, Sumbersari. Perioode 20092010.

Dokumentasi. Sejarah Pondok Pestren Darussalam Sumbersari, preode 2008-2009 M.

Fauziddin, Moh., Santi, Novi Nitya, Pekembangan Peserta Didik, Pada Anak Usia Dasar. t.t.p., t.p.: 2012.

Hasan, Maimunah. Pendidikan Anak Usia Dini . Bandung: Diva Prees 2009.
Hadi, Sutrisno. Metodologi Reserch. Yogyakarta; penerbit psikologis, universitas Gajahmada, 1986.

Hasil Observasi Di Kelas TK Plus Darul Athfal, Tanggal 2 Mei 2014 jam 08.00-09.00 WIB.

Hasil Observasi Di Kelas Tk A, Tanggal 7 Mei 2014 jam 08.00-09.00 WIB.

Hasil Observasi Di Kelas Tk B, Tanggal 7 Mei 2014 jam 09.00-09.30 WIB.

Hasil Observasi Peneliti di Lapangan, di TK Plus Darul Athfal Sumbersari Kencong Kepung Kediri, , Rabu, 13 Mei 2015, jam: 09.00-10.00 WIB.

Haryati. Aktifitas Pengisi Kegiatan PAUD. T.t.p: Tugu Publisher:2012.

http://childrengarden. Wardpress. Co /2010/04/02.

Tahap Perkembangan Anak Dalam Menulis, di akses tanggal 15 April 2011.

Luthfi, Moch.Saikhuni. Implementasi Pembelajara Al-Qur'an Melalui Metode Jibril Bagi Santri Tafidzhul Qur'an Pon-Pes Bidayatul Hidayah, Mojogeneng Jatirejo Mojokerto. September 2008.

Khotimah, Siti Khorriyatul. Perkembangan Anak. Surabaya:Dakwah Digital Press, 2009.

Masyhud, Mini Rose. “Asah Kecerdasan Majemuk Si Kecil Dengan Morinaga MI Playolan” jawa pos, 26 April 2015.

Sulthon, M.. et.al. Manajemen Pondok Pesantren Jakarta; Diva Pustaka, 2003.

Milles dan Huberman. Analisis Data Kualitatif Tentang Metode-Metode Baru, terj. Tjetjep Rohendi. Jakarta; UI Press, 1992.

Muthohir, Ahmad. Ideologi Pendidikan Pesantren (Pesantren di Tengah Arus Ideologi-ideologi Pendidikan). Semarang: Pustaka Rizki Putra, 2007.

Nasution. Metode Penelitian Naturalistik Kualitatif. Surabaya, FKIP, 1988.

Nata, Abuddin. Metodologi Studi Islam. Jakarta: PT Raja Grafindo Persada, 2007.

Rahmawati, Yeni. Kurniati, Euis. Strategi Perkembangan Kreativitas Pada Anak Usia Taman Kanak-Kanak. Jakarta: Kencana Prenada Media Group, 2010.

Ramayulis. Ilmu Pendidikan Islam. Jakarta: Kalam Mulia, 2008.

Poerwadarminta W.J.S. Kamus Umum Bahasa Indonesia. Jakarta; Balai Pustaka, 1991. cet. II 
Sardiman. Interaksi Belajar Mengajar Tentang Pendidikan Pra Sekolah. Jakarta: Raja Grafindo 2007.

Soetopo. Konsep-konsep Dasar Penelitian Kualitatif . Surabaya , FKIP, 1988.

Susanto, Ahmad. Perkembangan Anak Usia Dini. Jakarta: Kencana, 2011.

Sugiyono. Metode Penelitian Kuantitatif, Kualitatif dan $R \& D$. Bandung: Alfabeta, 2009.

Sholeh, Abdul Rahman. Psikologi, Suatu Pengantar Dalam Perspektif Islam. Jakarta: Kencana,2008.

Syamsudin H.E. "Konsep Pendidikan Agama Islam”. Ta'lim Pendidikan Agama Islam . Januari,2009.

Syafi'i, Ahmad Musta'in. dkk, Al-Asma Al-Husna. Cara Belajar Cepat Abad 21metode Hanifida. Jombang: CV. Percetakn Fajar 2009.

Wawancara Dengan Ibu Nita Cahya Rista Nengseh, Selaku Guru TK Plus Darul Athfal, Pada Tanggal 04 Mei 2015, Jam 08.00-08.30 WIB.

Wawancara dengan Ibu Ani Ni'matus Sholihah Selaku Guru TK Plus Darul Atfhal, Pada Tanggal, 04 Mei 2015, Jam 08.30-09.00 WIB.

Wawancara dengan Ibu Rizkiatul Fauziyah Selaku Guru TK Plus Darul Atfhal, Pada Tanggal, 05 Mei 2015, Jam 09.00-09.30 WIB.

Wawancara Dengan Ibu Robi' Wafaul Husna Selaku Guru TK Plus Darul Atfhal, Pada Tanggal, 05 Mei 2015. Jam 09.30-10.00 WIB.
Wawancara Dengan Ibu Uun Nur Hamidah Selaku Guru TK Plus Darul Atfhal, Pada Tanggal, 05 Mei 2015, Jam 10.00-10.30 WIB.

Wawancara Dengan Ibu Lina Zumrotul Husna Selaku Guru TK Plus Darul Atfhal, Pada Tanggal, 06 Mei 2015, Jam 09.00-09.30 WIB.

Wawancara Dengan Ibu Lia Husnia, Selaku Kepala TK Plus Darul Athfal , Pada Tanggal 04 Mei 2015.Jam 09.30-10.00 WIB.

Wawancara Dengan Ibu Naily Syafa'ah, Selaku guru TK Plus Darul Athfal, Pada Tanggal 06 Mei 2015. Jam 10.15-10.45 WIB.

Yaumi, Muhammad dan Ibrahim Nurdin. Pembelajaran Berbasis, Kecerdasan Jamak (Multiple Intelligences). T.t.p., Kencana Prenada Media Group: 2013.

Undang-Undang Republik Indonesia No. 20 Tahun 2003 Tentang Sistem Pendidikan Nasional. Jogjakarta: Bening, 2010.

Wiyani, Novan Ardy. Pendidikan Karakter Berbasis Iman Dan Taqwa, Yokyakarta: Teras 2012.

Zaini, Wahid. Dunia Pemikiran Kaum Santri. Yogyakarta: LKPSM, 1995.

Copyright (C) 2018 Journal Dirasah: Vol. 1, No. 2, August 2018, p-ISSN: 2615-0212, e-ISSN; 26212838

Copyright rests with the authors

Copyright of Jurnal Dirasah is the property of Jurnal Dirasah and its content may not be copied or emailed to multiple sites or posted to a listserv without the copyright holder's express written permission. However, users may print, download, or email articles for individual use. https:/lejournal.stisfa-kediri.ac.id/index.php/dirasah 